\title{
ANALYSIS OF FLY ASH FOR MANUFACTURING OF MODERN MATERIALS
}

\author{
ANALIZA POPIOŁÓW LOTNYCH POD KĄTEM MOŻLIWOŚCI \\ WYTWARZANIA NOWOCZESNYCH MATERIAŁÓW
}

\author{
Janusz MIKUŁA ${ }^{1}$, Michał $Ł A C H^{1}$
}

\begin{abstract}
The paper presents the characteristic of combustion by-products which are fly ashes from coal combustion in pulverized-fuel boilers. The results of the studies of fly ashes from the Skawina SA power plant are presented. The research was conducted to show the possibility of using fly ash for the production of modern materials such as absorbents and zeolites and geopolymer binder. Physical and chemical properties of fly ashes, their grain morphology and particle size distribution are presented in the paper. A process for the preparation of zeolites and geopolymers based on fly ash is described and the results of certain properties of these materials are presented. The study contains a series of microscopic images of the structures of zeolites and geopolymers based on fly ash.

Keywords: coal combustion by-products, fly ashes, geopolymer, zeolite
\end{abstract}

Streszczenie: W pracy zaprezentowano wyniki badań ubocznych produktów spalania węgla jakimi są popioły lotne ze spalania węgla w kotłach pyłowych. Badania prowadzono pod kątem możliwości wykorzystania popiołów lotnych do produkcji nowoczesnych materiałów takich jak sorbenty i zeolity oraz spoiwa geopolimerowe. Przedstawiono wybrane właściwości popiołów lotnych z krajowych elektrociepłowni. Opisano sposób wytwarzania zeolitów oraz geopolimerów na bazie popiołów lotnych a także przedstawiono wyniki badań określonych właściwości tych materiałów. Opracowanie zawiera szereg zdjęć mikroskopowych otrzymanych struktur na bazie popiołów lotnych.

Słowa kluczowe: produkty spalania węgla, popioły lotne, geopolimer, zeolit

\section{INTRODUCTION}

Fly ashes are produced in the process of producing electricity and heat by burning coal. For decades, there was no idea of their large economic (industrial) use. They were placed in the landfill. The significant increase in the use of such ashes has been done in Poland and in the world during the past several years. Research are carried out on its multi-application

\footnotetext{
${ }^{1}$ Cracow University of Technology, Institute of Materials Engineering, al. Jana Pawła II 37
} 
industrial of fly ash for many years [1]. The fly ash are largely used economically due to the significant level of their use in the construction materials industry in Poland for the production of clinker, cement, concrete [2,3], lightweight aggregates and building ceramics. Currently the share of ash utilization in this industry is about $55-57 \%$. More than $30 \%$ ashes in Poland is used as a component of materials for filling underground workings in the mines in Upper Silesia. They are also used in road construction [4;5] for soil stabilization, embankments and dumps, construction of roads and dikes as well as in the paint industry [6]. Fly ash has been also applied in the production of molding [7].

The chemical and mineralogical composition of fly ash depends on the properties and composition of burned coal used in power plants. Due to the rapid cooling of the material, fly ash consists mainly of (50-90\%) of the substance in the form of glassy mineral particles. The small amount of particles is in crystalline form. The most important minerals identified in the fly ash from coal are: magnetite $0.8-6.5 \%$; hematite $1.1-2.7 \%$; quartz $2.2-8.5 \%$; 6.5-9.0\% mullite; free calcium oxide up to $3,5 \%$. Other minerals such as wustite, goethite, pyrite, calcite, anhydrite and periclase present in amounts of from trace to 2,5\%. In terms of the composition of the oxide fly ash are particularly rich in $\mathrm{SiO}_{2}, \mathrm{Al}_{2} \mathrm{O}_{3}$ and $\mathrm{Fe}_{2} \mathrm{O}_{3}$. They also contain other oxides such as $\mathrm{CaO}, \mathrm{MgO}, \mathrm{MnO}, \mathrm{TiO}_{2}, \mathrm{Na}_{2} \mathrm{O}, \mathrm{K}_{2} \mathrm{O}, \mathrm{SO}_{3}$. Fragmentation of ash is usually measured by sieve analysis, and may be performed using a dry or wet process. Ash particles differ in their size and shape. There are spherical particles with rounded (Fig. 1), irregular or rectangular shapes [8].
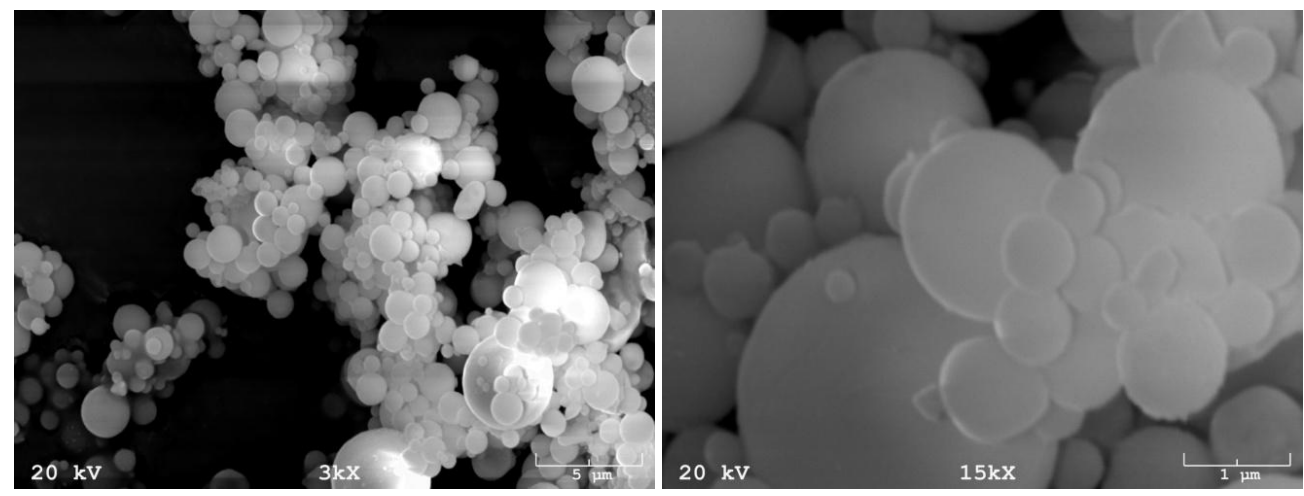

Figure 1. Fly ash with a very high fineness - the fraction of the permeate

Due to its pozzolanic properties, low calcium fly ash as an additive for cement mixes have a positive effect on the characteristics of concrete, such as: increased strength and chemical resistance, reduced porosity and water consumption, reduction of swelling. Because of the pozzolanic and hydraulic activity is possible to achieve a low permeability layers of ash used in geotechnical engineering and land reclamation. The largest hydraulic activity exhibit high calcium ash containing from 10 to $40 \%$ of free $\mathrm{CaO}$ [9]. The addition of fly ash in the concrete has a positive effect on the reduction of the diffusion coefficient and the rate of migration of chlorides [10]. Fly ashes can be successfully used as material or as an additive to mineral soil in the construction of landfill sites [9]. In many countries around the world fly ash find wider application. Fly ash are used in road construction, among other things, to the 
construction of asphalt pavements as a filler, concrete paving, soil stabilization, in the concrete cement and embankments made by hydromechanization, in the United States. According to the authors [11] a mixture of fly ash and ash-slag can be used in all layers of the surface structure of the site grading and embankments by the foundation to asphalt mixtures [11]. The above-mentioned application are known and used for decades.

Due to its characteristics of fly ash for many years, are also used for the synthesis of zeolite [10,11,14-17] and for the production of binder or geopolymer cements [18-21]. These are relatively new materials with specific properties that are wider and wider applicated in many industries. Geopolymers apply mainly in construction and in the future may replace conventional concretes based on portland cement. Zeolites as a natural minerals have been known for centuries. However recently researchers, began to deal with the obtaining of synthetic zeolites, among others, from fly ash. This paper presents examples of the results of research into the possibility of obtaining zeolites and geopolymers from fly ash.

\section{RESEARCH METHODOLOGY}

The analysis of the particle morphology and chemical composition performed on a scanning electron microscope JEOL JSM-820 using microprobe EDS. The test specimens for SEM were sprayed with a thin layer of gold on the coater JEOL JEE-4X. Samples of fly ash to study microstructural have been previously prepared. Small amounts of ashes were dried to a constant weight and placed on a substrate providing discharge loads from the sample.

Technical sodium hydroxide flakes and an aqueous sodium silicate solution of R-145 module 2.5 and a molar density of about $1.45 \mathrm{~g} / \mathrm{cm}^{3}$ were used to produce geopolymers. The mixture was not used distilled water - only tap water. The alkaline solution was prepared in this way that the solid sodium hydroxide was poured over an aqueous solution of sodium silicate and water. The solution was thoroughly mixed and leaved to reach homogeneity and temperature stabilization.

Solid components of the mixture which is fly ash with the possible addition of sand were dry mixed, until a uniform mixture, and alkaline solution was added and thoroughly mixed. Mixing was performed in a laboratory mixer. After obtaining a homogeneous mass with the consistency of thick plastic, the mixture was transferred into molds, which were placed on the vibrating table. Prepared binders geopolymer was annealed in the oven for 24 hours at $75^{\circ} \mathrm{C}$ at the atmospheric pressure. After 24 hours, samples were drawn and demolding. Compressive strength tests were carried out after 28 days from the demolding of the samples. Until the test, the samples were stored at ambient temperature. Studies were also performed on the compressive strength of the geopolymer samples after exposure at $800^{\circ} \mathrm{C}$ for $4 \mathrm{~h}$ in silite laboratory oven. Heating and cooling procedure was carried out in the furnace.

Alkaline activation processes - synthesis of zeolite was conducted using the fly ash from the same origin as in the case of geopolymer binder.

As activator was used the sodium hydroxide $\mathrm{NaOH}$ (technical purity $>98 \%$ ) in the form of flakes. The water used to prepare the solutions of both processes as well as filtering and washing of the obtained materials was distilled water. The processes of filtration and washing was carried out using a filter paper for qualitative analysis made from pure cellulose and cotton linter. The time of filtering was set to 10 [s]. Measured amounts of fly ash was mixed with an aqueous solution of sodium hydroxide of specified concentrations. For comparison the efficiency of the normal hydrothermal synthesis with fusion method combined with 
hydrothermal activation was carried out, the fly ash sintering with $\mathrm{NaOH}$ at a temperature of $550^{\circ} \mathrm{C}$ for sample 1 . Sintering was performed in a muffle furnace in the air and the sintering time was 4 hours. After sintering the resulting material was ground and treated hydrothermal synthesis in the same conditions as the other samples which were not sintered. The solutions was prepared as described above, were thoroughly mixed and placed in a polypropylene cylindrical vessels with a capacity of $1000 \mathrm{ml}$. The containers were sealed and placed in a drying oven at $80^{\circ} \mathrm{C}$. After zeolitization process samples were cooled to room temperature and then filtered to remove residual solution after activation. After filtration, the sample was washed with distilled water to obtain a $\mathrm{pH}$ of about 10. Typically, it consisted of 8-12 times flushing $1000 \mathrm{ml}$ of distilled water.

The final step of the synthesis the samples were drying at $105^{\circ} \mathrm{C}$. The drying time was equal to 6 hours. Measurements of porosity and specific surface area was based on the theory of multilayer adsorption Braunauer-Emmett-Teller, BET with using sorptomat - ASAP 2020 (Micromeritics).

\section{RESEARCH MATERIAL AND RESULTS}

The study used fly ashes from power plant in Skawina. The composition of the oxide and the physical and chemical properties are shown in Tables 1-3.

Table 1. Oxide content in fly ash

\begin{tabular}{|c|c|c|c|c|c|c|c|c|c|c|c|}
\hline Oxide & $\mathrm{SiO}_{2}$ & $\mathrm{Al}_{2} \mathrm{O}_{3}$ & $\mathrm{Fe}_{2} \mathrm{O}_{3}$ & $\mathrm{CaO}$ & $\mathrm{MgO}$ & $\mathrm{Na}_{2} \mathrm{O}$ & $\mathrm{K}_{2} \mathrm{O}$ & $\mathrm{SO}_{3}$ & $\mathrm{TiO}_{2}$ & $\mathrm{P}_{2} \mathrm{O}_{5}$ & $\mathrm{BaO}$ \\
\hline $\begin{array}{c}\text { Content } \\
{[\%]}\end{array}$ & 55.89 & 23.49 & 5.92 & 2.72 & 2.61 & 0.59 & 3.55 & 0.16 & 1.09 & 0.82 & 0.20 \\
\hline
\end{tabular}

Table 2. Chemical properties of fly ash

\begin{tabular}{|c|c|c|c|c|c|c|}
\hline Parameter & $\begin{array}{c}\mathrm{SiO}_{2} \\
\text { reactive }\end{array}$ & $\begin{array}{c}\mathrm{CaO} \\
\text { free }\end{array}$ & $\mathrm{Na}_{2} \mathrm{O}_{\text {eq }}$ & $\begin{array}{c}\text { Chlorides } \\
(\mathrm{Cl}-)\end{array}$ & $\begin{array}{c}\text { Soluble } \\
\text { phosphates as } \\
\mathrm{P}_{2} \mathrm{O}_{5}\end{array}$ & $\begin{array}{c}\text { Loss on } \\
\text { ignition }\end{array}$ \\
\hline $\begin{array}{c}\text { Result } \\
{[\%]}\end{array}$ & 35.86 & 0.02 & 4.76 & 0.034 & $\begin{array}{c}0.0008(8 \\
\mathrm{mg} / \mathrm{kg})\end{array}$ & 2.84 \\
\hline
\end{tabular}

Table 3. Physical properties of fly ash

\begin{tabular}{|c|c|c|c|c|c|}
\hline \multirow{2}{*}{ Parameter } & \multirow{2}{*}{ Fineness [\%] } & \multirow{2}{*}{$\begin{array}{l}\text { Density } \\
{\left[\mathrm{kg} / \mathrm{m}^{3}\right]}\end{array}$} & \multirow{2}{*}{$\begin{array}{c}\text { Pozzolanic } \\
\text { activity index } \\
\text { after } 28 \text { days } \\
{[\%]}\end{array}$} & \multicolumn{2}{|c|}{ Beginning of the binding [min] } \\
\hline & & & & $\begin{array}{c}\text { Cement } \\
\text { comparative }\end{array}$ & $\begin{array}{c}75 \% \text { cement } \\
\text { comparative }+25 \% \text { fly } \\
\text { ash }\end{array}$ \\
\hline Result & $34.2 \pm 0.3$ & $2180 \pm 20$ & $75 \pm 3$ & $175 \pm 10$ & $240 \pm 15$ \\
\hline
\end{tabular}

The morphology of the powder particles is shown in Figure 2. The fly ash particles have a smooth. spherical shape and the size does not exceed 100 microns (most of the particles have a size less than 50 microns). Unburned carbon particles were observed as components of substantially porous surface area. These particles have a size significantly larger than the particles of fly ash (usually above 200 microns). Examples of particle morphology of the unburned carbon present in the fly ash is shown in Figure 3. 


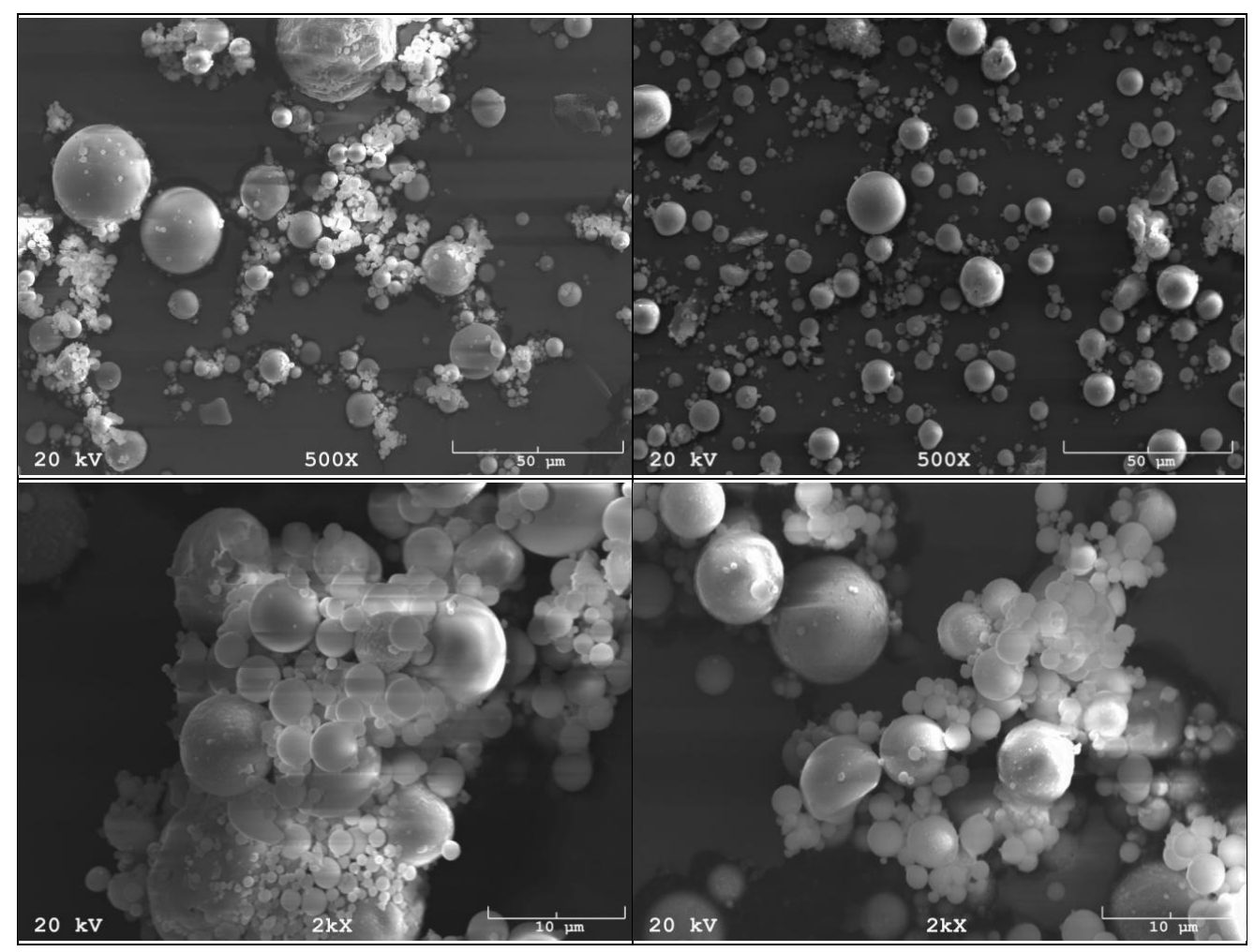

Figure 2. Morphology of typical fly ash from pulverized coal boilers

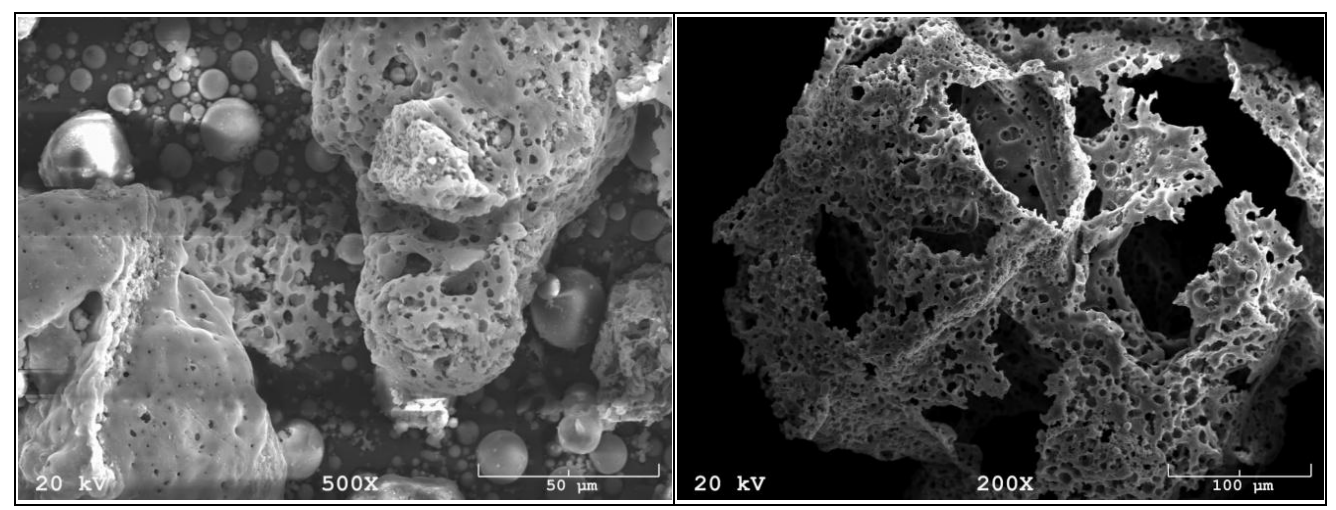

Figure 3. Morphology of unburned carbon present in fly ash 
Figure 4 shows the particle size distribution of fly ash used for the test. The largest share of the particles less than 56 microns was observed - about $60 \%$. The particles greater than 100 microns are practically unburned carbon and cenosphere found in the ashes.

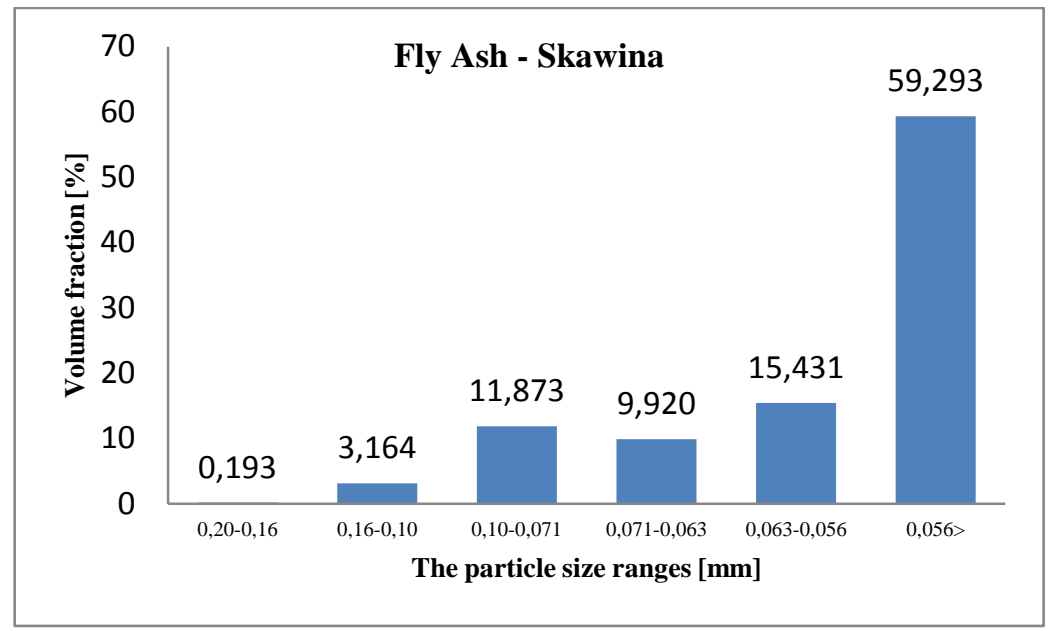

Figure 4. The percentage of the different fractions contained in the fly ash

Microstructures of geopolymer materials obtained on the basis of fly ash are shown in Figures 5 and 6. Figure 5 shows the microspheres in the matrix of geopolymers - hollow spheres present in the fly ash. Taking into account the mechanical properties of the binder or geopolymer concrete. the presence of the microspheres is disadvantageous because it reduces the compressive strength of such materials.

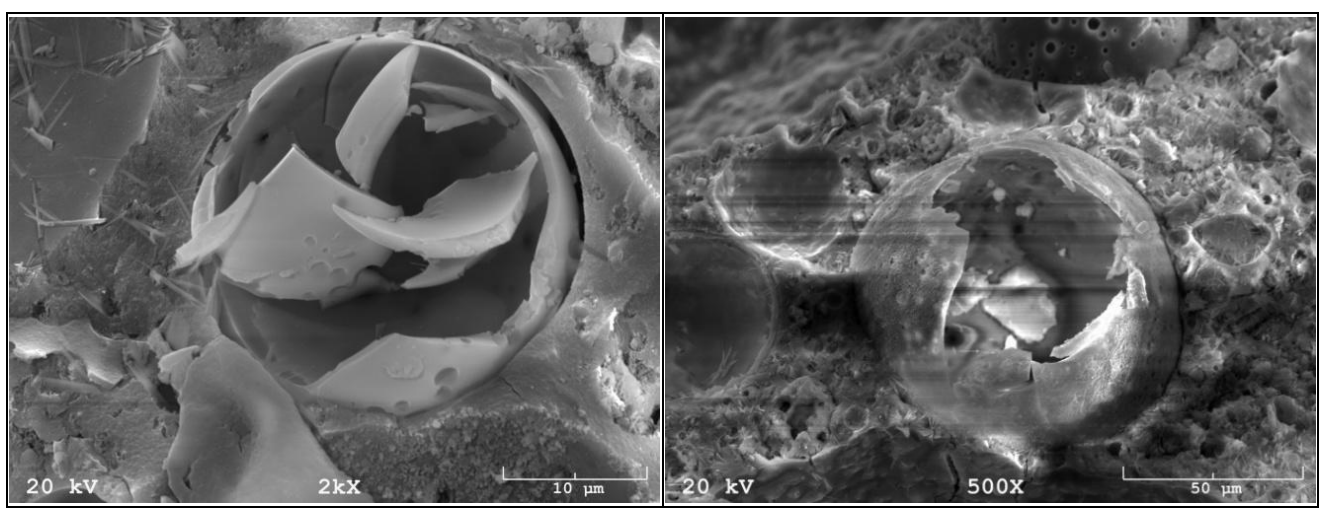

Figure 5. Microspheres in geopolymer matrix

Figure 6 shows an example of the microstructure of geopolymers obtained on the basis of fly ash from the power plant in Skawina. Cracks visible in the photographs are the result of the earlier realized tests for compressive strength. The geopolymer matrix are shown in the form 
of zeolite crystals on the surface of the unreacted ash and in the form of crystalline aggregates. The apparent porosity is characteristic both for traditional concrete based on Portland cement and for geopolymers. It is the result of the entry of air to the mass of geopolymers while stirring operation and the results of the creating of gases occurring due to the reaction between the components of the ashes and activators. Due to limit the porosity which causes reduction of mechanical properties vibratory compaction of the material is used.
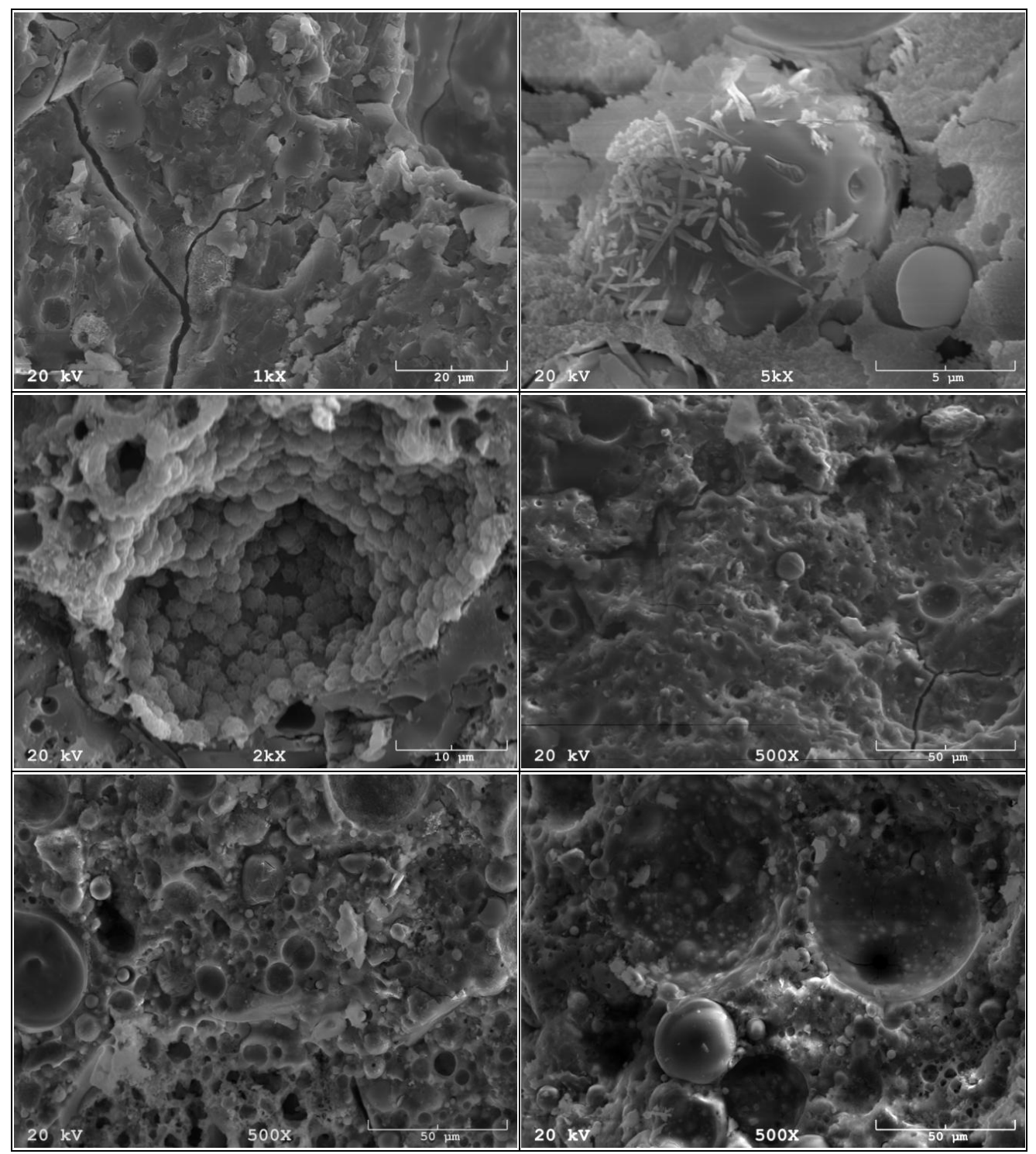

Figure 6. Sample microstructure of geopolymers 


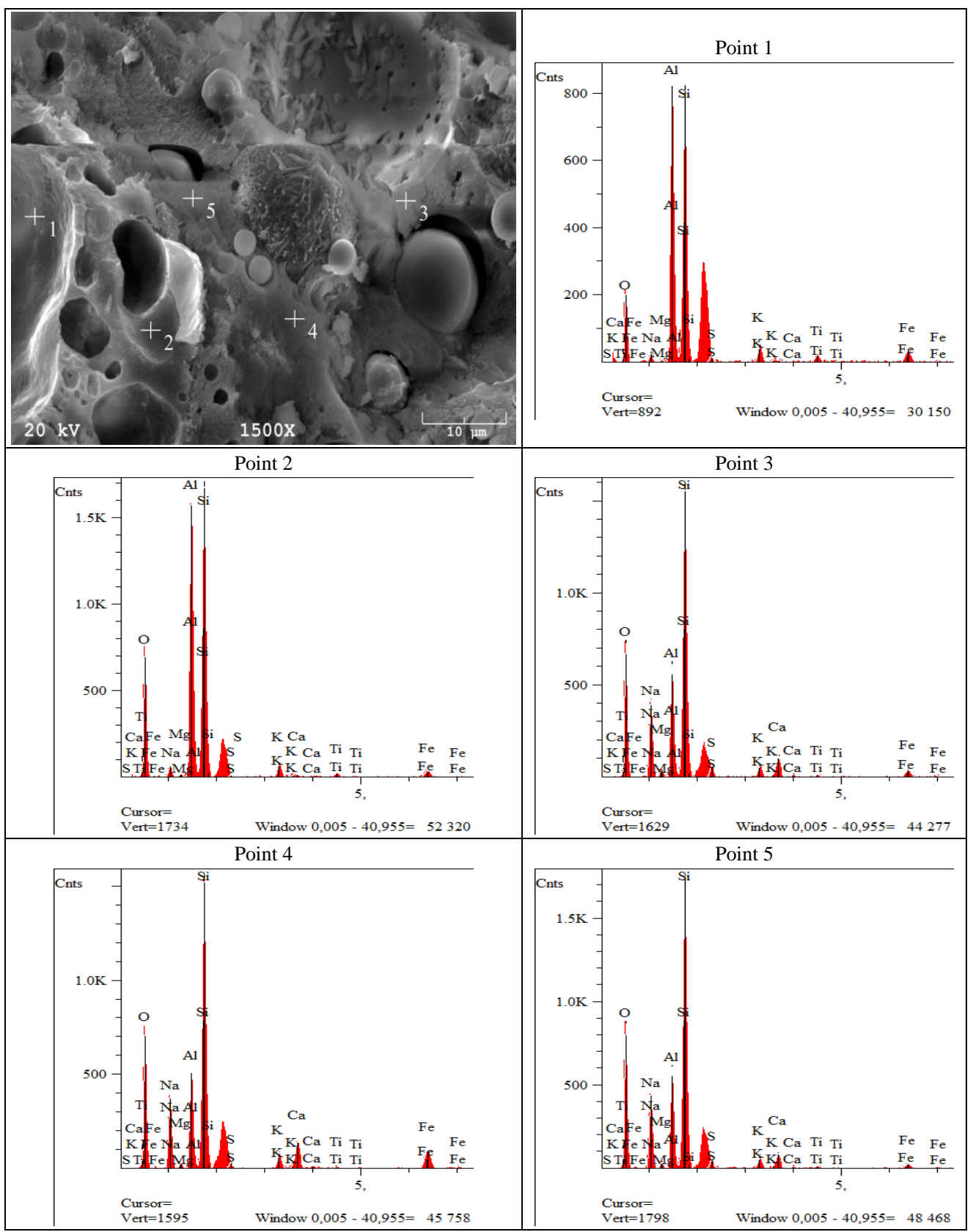

Figure 7. Analysis of the chemical compositions of the geopolymer binder 
Microstructure of geopolymer materials may differ from each other depending on many factors. Depending on the type of ashes used in their manufacture. they may differ in their degree of conversion. Clear can be seen the fly ash particles that retain their shape and do not dissolve. This happens especially when the ash particles are coated with compounds of other elements. eg. iron. There can also be seen particles of unburned coal or flue gas desulfurization products in the microstructure. Depending on the type of used filler and the aggregates. the microstructure of geopolymer may represent different grain silica or other minerals.

The analysis of the chemical composition of the geopolymer binder produced on the basis of fly ash from Skawina is shown in Figure 7. Points 3. 4 and 5 illustrates the typical geopolymer composition based on fly ash. There are mainly elements such as silicon. aluminum and sodium. Additionally there is a smaller concentration of elements such as calcium. iron and potassium. In the points of 1 and 2 . we observed a structure that has not been dissolved in the process of geopolymerization. The increased ratio of aluminum to silicon and a very low concentration of alkaline substances - which shows does not react between these components and activator introduced into the mixture.

Table 4 shows the results of checking the compressive strength of geopolymers. After 28 days of geopolymers without fillers and aggregates. characterized by a compressive strength equal to about $65 \mathrm{MPa}$. After exposure at $800^{\circ} \mathrm{C}$ the compressive strength in this case is about $20 \mathrm{MPa}$. In the case where the geopolymers used as a filler sand (50\%). the compressive strength after 28 days is approximately $44 \mathrm{MPa}$. After exposure at $800^{\circ} \mathrm{C}$ this strength is about $24 \mathrm{MPa}$. Addition of fillers and aggregates has a positive effect on the mechanical properties at elevated temperatures.

Table 4. Compressive strength of geopolymers

\begin{tabular}{|c|c|c|c|}
\hline & $\begin{array}{c}\text { After 14 days } \\
{[\mathrm{MPa}]}\end{array}$ & After 28 days [MPa] & $\begin{array}{c}\text { After 28 days + 4 } \\
\text { hours exposure in } 800 \\
{ }^{\circ} \mathrm{C}[\mathrm{MPa}]\end{array}$ \\
\hline $\begin{array}{c}\text { Geopolymer binder } \\
\text { 100\% fly ash }\end{array}$ & 62.1 & 64.5 & 19.4 \\
\hline $\begin{array}{c}\text { Geopolymer binder } \\
\text { with 50\% sand }\end{array}$ & 35.8 & 43.4 & 24.1 \\
\hline
\end{tabular}

The table below presents the results of the processing of fly ash in zeolite materials in the processes of hydrothermal synthesis.

Table 5. Zeolite synthesis parameters

\begin{tabular}{|c|c|c|c|c|}
\hline Number & Method & $\begin{array}{c}\text { Concentration of fly } \\
\text { ash }\end{array}$ & $\begin{array}{c}\text { Activator } \\
\text { concentration }\end{array}$ & Activation time \\
\hline 1 & Fusion (Hydrothermal) & $200 \mathrm{~g} / \mathrm{dm}^{3}$ & $10 \mathrm{Mol} / \mathrm{dm}^{3}$ & $24 \mathrm{~h}-80^{\circ} \mathrm{C}$ \\
\hline 2 & Hydrothermal & $200 \mathrm{~g} / \mathrm{dm}^{3}$ & $3 \mathrm{Mol} / \mathrm{dm}^{3}$ & $24 \mathrm{~h}-80^{\circ} \mathrm{C}$ \\
\hline 3 & Hydrothermal & $200 \mathrm{~g} / \mathrm{dm}^{3}$ & $10 \mathrm{Mol} / \mathrm{dm}^{3}$ & $24 \mathrm{~h}-80^{\circ} \mathrm{C}$ \\
\hline 4 & Hydrothermal & $200 \mathrm{~g} / \mathrm{dm}^{3}$ & $15 \mathrm{Mol} / \mathrm{dm}^{3}$ & $24 \mathrm{~h}-80^{\circ} \mathrm{C}$ \\
\hline
\end{tabular}

Hydrothermal synthesis process was carried out for 4 samples of ashes from Skawina. Samples 2 and 3 were subjected to a process of synthesis $\mathrm{NaOH}$ at equal molar concentrations 
of 3.10 and $15 \mathrm{~mol} / \mathrm{dm}^{3}$. Sample number 1 was further subjected to a process of fusion that is sintering of solid $\mathrm{NaOH}$ with fly ash. Reaction time and temperature were constant.

Below in Figure 8 were presented the microstructure of materials obtained after hydrothermal synthesis processes of fly ash from power plant in Skawina. Presents the most characteristic products of the synthesis was shown. Due to the fact that the composition of the ash is very variable. Synthesis process efficiency never reaches $100 \%$ because as a result of the synthesis will often produce several different zeolites or part of the material remains unreacted. During the hydrothermal synthesis a smooth surface of fly ash particles become roughened and the surface becomes more developed due to the reaction with alkali and crystallized zeolites appear on the surface. Zeolites can also crystallized from the components as which are dissolved in solution.

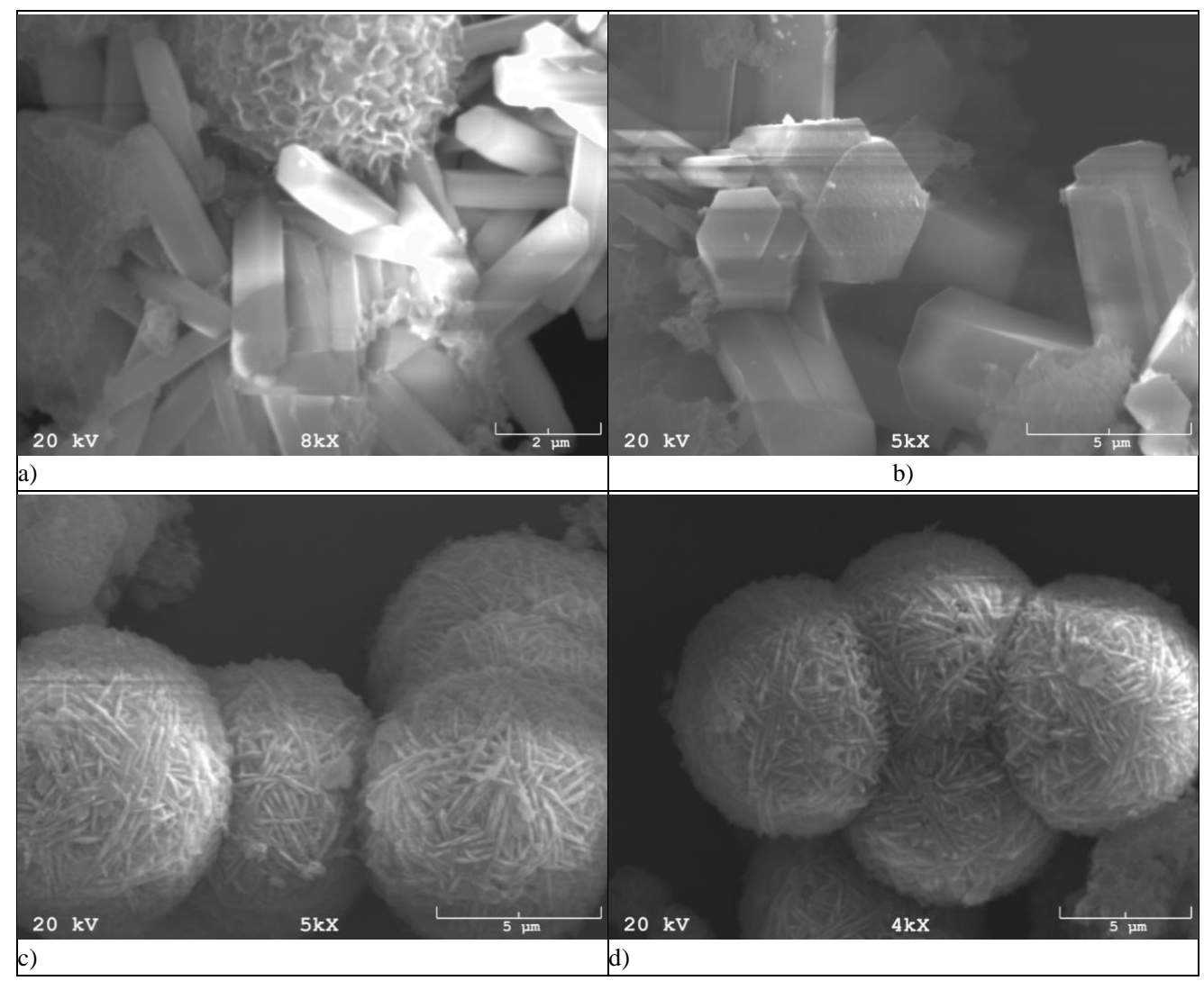




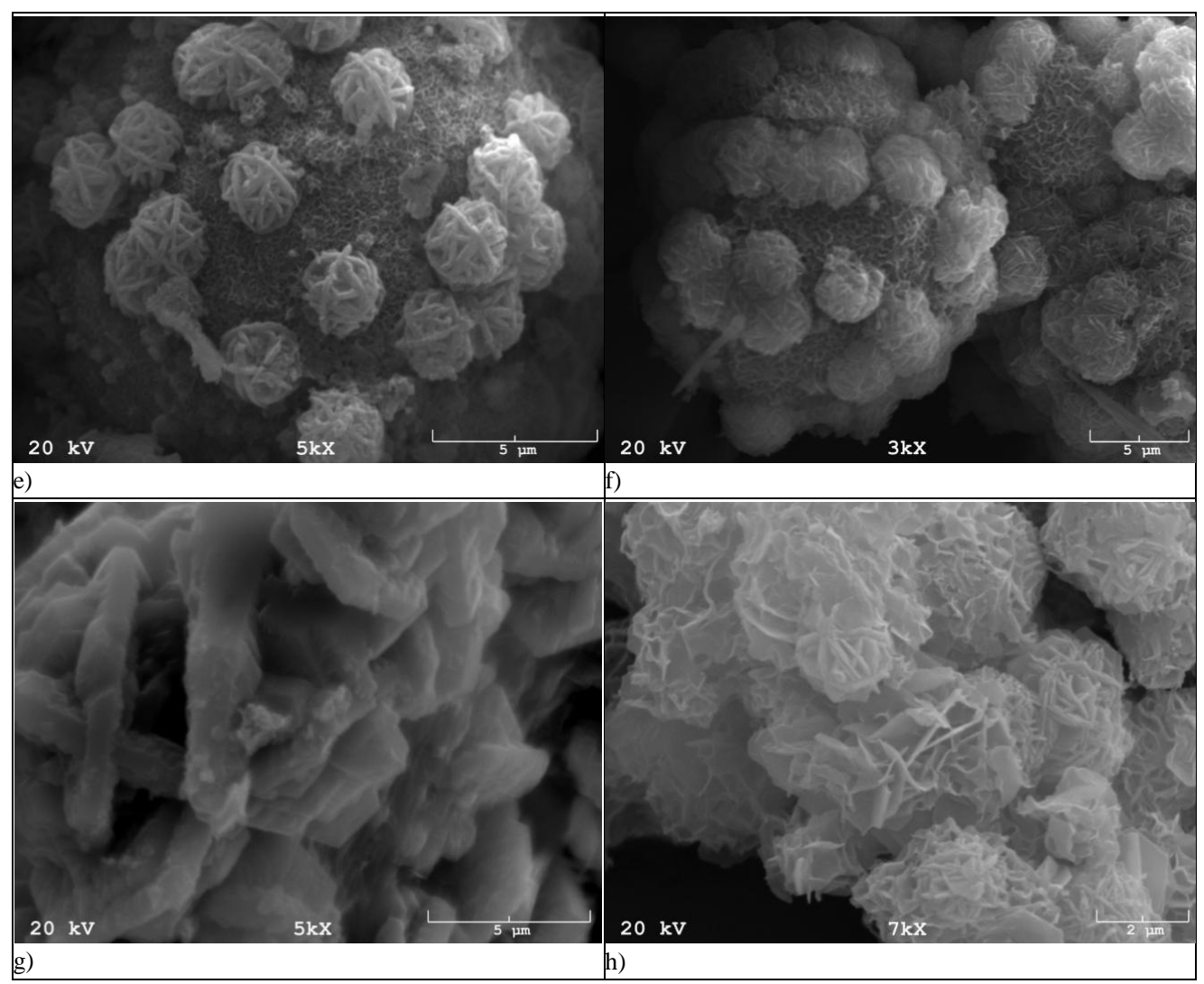

Figure 8. The morphology of the zeolite products based on fly ash: a.b) sodalite; c.d.e.f.g) zeolite A and zeolite P; h) tobermorite

Microphotographs in Figure 9 showed zeolite structures which were obtained under different conditions of synthesis.

Table 6 shows the results of porosimetric tests of materials obtained by synthesis of fly ash. The highest value of the specific surface area has a sample number 2. With increasing molar ratio of $\mathrm{NaOH}$ specific surface area decreases. When using further fusing method . an increase in the specific surface area was observed compared to the sample 3 , which also proceeded by hydrothermal synthesis at a concentration of $10 \mathrm{~mol} / \mathrm{dm}^{3}$. BET surface area values are relatively low compared to commercial zeolites due to significant influence of impurity the ashes. Only a part of the material has reacted and the average value of the surface of the samples are low because of that. Mesoporous materials were also created as a result of synthesis. 


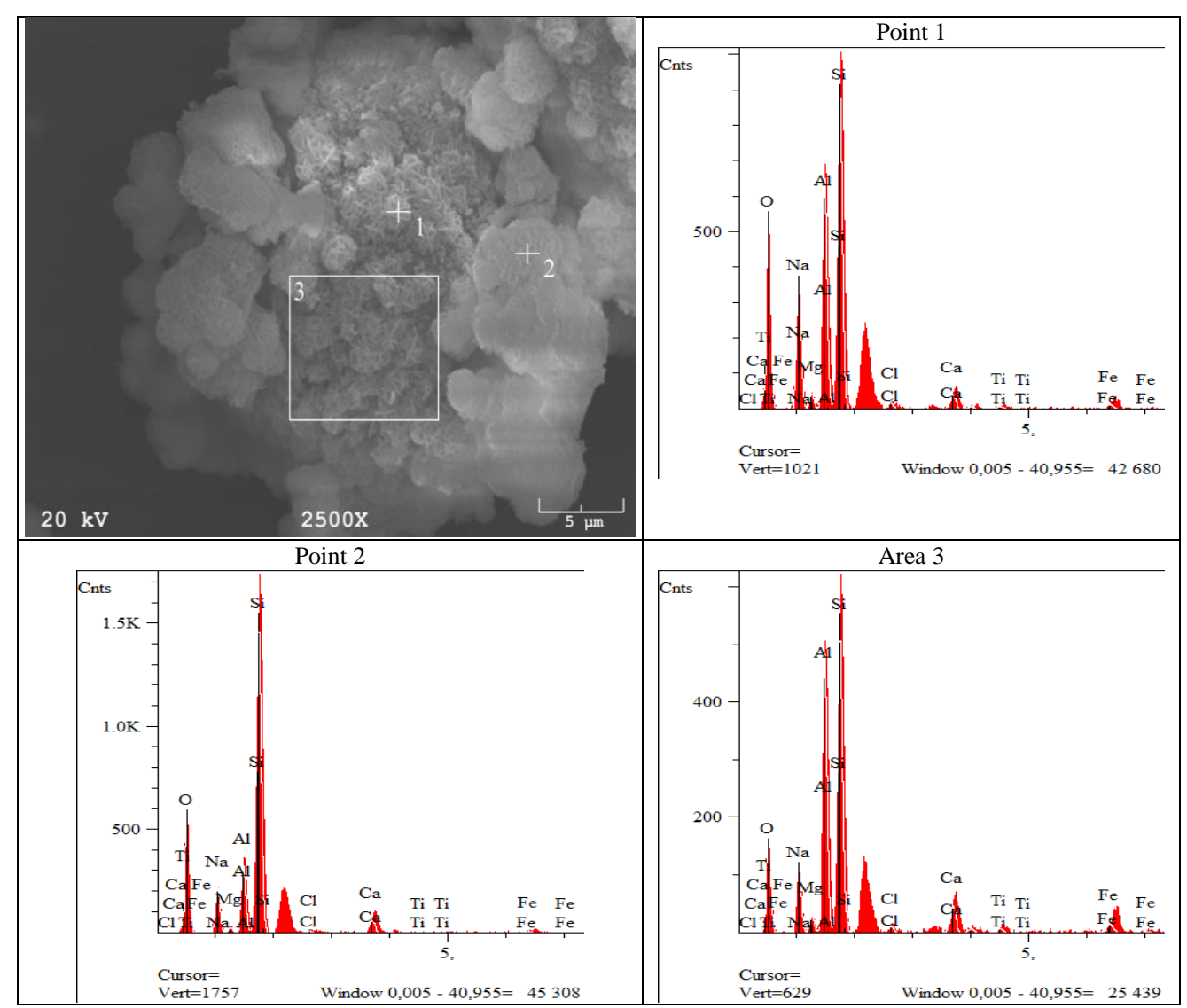

Figure 9. Analysis of the chemical compositions of the zeolitic materials

Table 6. The porosimetric results of received materials

\begin{tabular}{|c|c|c|c|}
\hline Number & $\begin{array}{c}\text { BET surface } \\
{\left[\mathrm{m}^{2} / \mathrm{g}\right]}\end{array}$ & $\begin{array}{c}\text { Langmuir surface } \\
{\left[\mathrm{m}^{2} / \mathrm{g}\right]}\end{array}$ & $\begin{array}{c}\text { t-Plot micropore } \\
\text { volume }\left[\mathrm{cm}^{3} / \mathrm{g}\right]\end{array}$ \\
\hline 1 & 83.3766 & 102.1648 & 0.004271 \\
\hline 2 & 180.5113 & 214.7915 & 0.055679 \\
\hline 3 & 61.4232 & 77.2306 & 0.005927 \\
\hline 4 & 24.6102 & 30.6638 & 0.003965 \\
\hline
\end{tabular}

\section{SUMMARY AND CONCLUSIONS}

The paper presents the possibility of using fly ash from black coal combustion in pulverized state for the production of modern materials such as geopolymer binder and zeolites. The study was conducted using fly ash from Skawina Power Plant. The study results showed the usefulness of this type of ash in the manufacture of zeolites. geopolymers and mesoporous materials. Geopolymers produced on the basis of fly ash from the Skawina Power Plant for 
appropriately selected recipe activating substances have a compressive strength of about 40$60 \mathrm{MPa}$. They also have a very high resistance to high temperatures. Resulting fly ash zeolite and mesoporous materials can be widely used as sorbents mineral or molecular sieves.

\section{BIBLIOGRAPHY}

[1] GALOS K.; ULIASZ-BOCHEŃCZYK A.; Źródła i użytkowanie popiołów lotnych ze spalania węgli w Polsce; Gospodarka Surowcami Mineralnymi; Tom 21. 2005. Zeszyt 1.

[2] DOMOSŁAWSKI W., PUSHKARIOVA J.; Poprawa trwatości betonu przy pomocy konwencjonalnych popiołów lotnych. IV Międzynarodowe Forum Gospodarki Odpadami „Systemy Gospodarki Odpadami”. 27 maja 2001.

[3] ZAPOTOCZNA-SYTEK G.; ŁASKAWIEC K.; GĘBAROWSKI P.; i inni; Popioły lotne nowej generacji do produkcji autoklawizowanego betonu komórkowego; Monografia. Warszawa 2013

[4] ŁUCZAK-WILAMOWSKA B.; Możliwość zastosowania popiołów - odpadów przemysłu energetycznego - do uszczelniania i rekultywacji składowisk odpadów; Biuletyn Państwowego Instytutu Geologicznego 446:477482. $2011 \mathrm{r}$.

[5] SYBILSKI D. (Kierownik tematu); Ocena i badania wybranych odpadów przemystowych do wykorzystania w konstrukcjach drogowych; Instytut Badawczy Dróg i Mostów w Warszawie; Listopad 2004.

[6] SZPONDER-KOŁAKOWSKA D.K.; TRYBALSKI K.; Nowoczesne metody $i$ urzadzenia pomiarowe $w$ badaniu właściwości surowców i odpadów mineralnych; AGH. Kraków 2104.

[7] BALIŃSKI A.; Recykling odpadowych popiołów lotnych powstajacych ze spalania węgla kamiennego w aspekcie wytwarzania mas formierskich; Prace Instytutu Odlewnictwa. 2008. Tom XLVIII. Zeszyt 3.

[8] WESCHE K.; Fly Ash In Concrete. Properties and Performance; E\&FN SPON. London 1991.

[9] GLINICKI M.A.; JÓŹWIAK-NIEDŹWIECKA D.; GIBAS K.; Ocena przepuszczalności betonu z popiołem lotnym wapniowym- koncepcja badań; Materiały konferencyjne; Część II; Wykorzystanie popiołów lotnych w przemyśle materiałów budowlanych.

[10] FRANUS W.. Material zeolitowy typu X otrzymany z popiotu lotnego $w$ wyniku syntezy hydrotermalnej $i$ niskotemperaturowej. Budownictwo i Architektura 7 (2010) 25-34.

[11] SUCHECKI T.T.; Zeolity z popiotów lotnych. Otrzymywanie i aplikacje w inżynierii środowiska; Ossolineum 2005.

[12] FRANUS W., WDOWIN M.; Wykorzystanie popiołów lotnych klasy $F$ do produkcji materiału zeolitowego na skale póltechniczna; Polityka Energetyczna; T14. Z2. 2011.

[13] F. MICHALIKOWA i inni; Technologie przeróbcze uszlachetniania. zawierających części palne. popiolów lotnych $z$ weggli kamiennych spalanych $w$ elektrocieplowniach; Journal of The Polish Mineral Engineering Society. styczeń-grudzień 2010.

[14] ŻYGADŁO M.; SEWERYN A.; WOŹNIAK M.; Synteza zeolitów na bazie popiołów lotnych z wybranych instalacji odzysku ciepta; Archiwum Gospodarki Odpadami i Ochrony Środowiska; Vol. 12 nr 1 (2010). p. 15 26.

[15] ŚCIUBIDŁO A; MAJCHRZAK-KUCĘBA I; NOWAK W; Wpływ składu chemicznego popiołów lotnych na efektywność procesu syntezy zeolitów Na-X; Polska Akademia Nauk Komitet Inżynierii Środowiska. ; vol.59; (2009); str. 225-237.

[16] BUKALAK D.; MAJCHRZAK-KUCĘBA I.; NOWAK W.; Wpływ zawartości Si i Al w popiele lotnym na tworzenie się frakcji zeolitowych typu Na-P1; III Ogólnopolski Kongres Inzynierii Środowiska 13-17 września 2009; Lublin 2009.

[17] GUISNET M.; GILSON J.P.; Zeolites for Cleaner Technologies; Imperial Collage Press.

[18] DAVIDOVITS J.: Geopolymer chemistry and application. 2008.

[19] PROVIS J.L.. J.S.J. VAN DEVENTER: Geopolymers: structure. processing. properties and industrial applications. 2009.

[20] PROVIS J.L.. J.S.J. van DEVENTER; Alkali Activated Materials; Springer. 2014.

[21] DAVIDOVITS J.; 30 Years of Successes and Failures in Geopolymer Applications. Market Trends and Potential Breakthroughs; Geopolymer 2002 Conference. October 28-29. 2002. Melbourne. Australia. 